\title{
ALTERNATIVE SUPPLEMENTS AND MS MEDIUM CONCENTRATIONS IN THE IN VITRO ESTABLISHMENT OF Dipteryx alata VOG.
}

\author{
SUPLEMENTOS ALTERNATIVOS E CONCENTRAÇÕES DE MEIO MS NO \\ ESTABELECIMENTO IN VITRO DE Dipteryx alata VOG.
}

\author{
Herick Fernando de Jesus SILVA ${ }^{1}$; Simone Abreu ASMAR ${ }^{2}$; \\ Rayssa Camargo de OLIVEIRA ${ }^{1}$; José Magno Queiroz LUZ ${ }^{3}$; Berildo de MELO ${ }^{3}$ \\ 1. Doutorando(a) do Programa de Pós-Graduação em Agronomia, Universidade Federal de Uberlândia - UFU, Uberlândia, MG, Brasil. \\ herickfernando@gmail.com; 2. Pós-Doutoranda, CAPES-Embrapa, UFU, Uberlândia, MG, Brasil; 3. Professor, Doutor, Instituto de \\ Ciências Agrárias- ICIAG - UFU, Uberlândia, MG, Brasil.
}

\begin{abstract}
Dipteryx alata Vog. (barueiro) is a native fruit of the Cerrado used in food and medicine. The species has never been domesticated and is currently at risk of extinction. Plant tissue culture is an important tool for the conservation of germplasm and for quick, large-scale propagation of quality seedlings. While, this technique has never been used with barueiro, it could be a valuable tool in the domestication of this species. The objective of this work is to evaluate concentrations of MS medium salts $(25,50,75$ and $100 \%)$ supplemented with coconut water $\left(100 \mathrm{~mL} \mathrm{~L}^{-1}\right)$, dwarf banana pulp $\left(60 \mathrm{~g} \mathrm{~L}^{-1}\right)$ or the absence of any supplement in the in vitro establishment of barueiro seeds (Dipteryx alata Vog). The experiment used a completely randomized design (CRD) with a $3 \times 4$ factorial scheme (three cultivation media types and four concentrations of MS salts) and three repetitions. The following characteristics were evaluated: germination rate, shoot length, largest root length, stem diameter, number of leaves, chlorophyll A, chlorophyll B , total chlorophyll, and the fresh and dry mass of the seedlings. The coconut water and banana pulp supplements did not improve the in vitro development of the barueiro seedlings and the full concentration of MS salts did not improve the initial development of the seedlings. However, the pure MS medium at a concentration of $25 \%$ MS salts was the best option for the in vitro establishment of Dipteyx alata.
\end{abstract}

KEYWORDS: Natural supplements. Culture medium. Brazilian savannah fruit tree. Baru.

\section{INTRODUCTION}

The Cerrado (Brazilian Savannah) is a valuable biome in Brazil that covers approximately 204 million hectares (22\% of Brazil), is home to the second greatest biodiversity on the planet and is the greatest agricultural frontier in Brazil (JUNQUEIRA et al., 2012). According to Silva et al., (2001), 58 fruit species with economic potential have been identified in the Cerrado, but this number might actually be as high as 100 .

The barueiro (Dipteryx alata Vog.) is a typical fruit tree of the Cerrado and is used in landscaping, construction, regional cooking and alternative medicine (FERREIRA, 1998). It is one of a few species that produces fruit with fleshy pulp during the dry season of the Cerrado, and as such, is an important food source for wildlife during this time of the year (SANO et al., 2004).

According to Martinelli et al. (2013), barueiro is at risk of extinction due to human activity. Junqueira et al. (2012) states that the widespread collection of most of the best fruit has resulted in strong genetic erosion and the natural perpetuation of inferior material. Therefore, it is important to develop propagation techniques that allow large-scale production of seedling, germplasm conservation and breeding programs. Plant tissue culture may become a valuable aid in micropropagation and other techniques for this species.

Several basic media formulations have been used in in vitro cultivation (NOGUEIRA et al., 2004). While no standard formulation exists, the MS medium (MURASHIGE; SKOOG, 1977) and subsequent modifications and dilutions have been successfully used with several species. Using an unmodified MS medium for woody plants has sometimes produced unsatisfactory results while compositions diluted in macronutrients have been more suitable (GRATTAPAGLIA; MACHADO, 1998).

Some studies have focused on reducing costs by adding organic supplements to the culture medium (MARTÍNEZ; GARCÍA, 2007; ARAÚJO et al., 2006b; VIEIRA et al., 2009; CAMPOS, 2010). These supplements also provide amino acids, vitamins, minerals and growth regulators, which are the most expensive components of the culture medium according to Araujo et al. (2006a).

Coconut water contains minerals, myoinositol, cytokinins, nucleotides and other organic compounds. The concentration of coconut water used in culture media ranges from 3 to $15 \%$ for the in vitro growth of many plant species. Coconut 
water is used to stimulate the growth of the callus, increase asymbiotic germination, form somatic embryos, induce pollen grain division and promote the development of immature embryos (CALDAS et al., 1998). The predominance of studies evaluating the addition of this liquid endosperm in the culture media are most focused on the in vitro cultivation of orchids. For woody plants using this supplement is still scarce, except for some species, such as Acrocomia aculeata and Hancornia speciosa (SOARES et al., 2011, PINHEIRO et al., 2001).

Banana pulp has been widely used in the in vitro cultivation of orchids given that it is a source of potassium and a rooting simulator ( $\mathrm{Su}$ et al., 2012). George et al., (2008) recommends banana pulp as a supplemental source of vitamins, amino acids and growth regulators. Furthermore, Torres et al. (2001) mentions that Banana pulp can provide other benefits in in vitro cultivation such as root thickening and/or growth. However, there are reports in the literature addressing the nutritional potential of banana pulp in vitro culture of woody species, all facing the Orchidaceae family.

Interest in conserving the genetic resources of the potentially endangered barueiro has resulted in the need to improve micropropagation protocols for this species. Thus, our objective was to evaluated the effect of different concentrations of MS salts and alternative supplements (coconut water and banana pulp) on the in vitro cultivation of $D$. alata.

\section{MATERIAL AND METHODS}

The study was carried at the Laboratory of Biotechnology at the Institute for Agricultural Science (ICIAG - Instituto de Ciências Agrárias) at the Federal University of Uberlândia (UFU). In October, 2013, mature fruit was collected from barueiros trees (Dipteryx alata Vog.) located within a rural zone of the municipality of Uberlândia, MG, Brazil.

In April, 2014, the seeds were removed from the fruit using a bench vise. Afterwards, the seeds were sterilized by first washing with liquid detergent under running tap water, followed by immersion in $70 \%$ alcohol for two minutes and then a second immersion in a sodium hypochlorite solution $2 \% \mathrm{v} / \mathrm{v}$ while stirring for 30 minutes. Next, the seeds were washed three times in distilled water and then placed in $150 \mathrm{~mL}$ glass flasks containing $40 \mathrm{~mL}$ of culture medium and autoclaved in a laminar flow chamber. All media were enriched with $6.5 \mathrm{~g} \mathrm{~L}^{-1}$ of agar and adjusted to a $\mathrm{pH}$ of 5.7 before autoclaving. One day before inoculation, the flasks containing the media were sealed with plastic lids and autoclaved at $121^{\circ} \mathrm{C}$ for 20 minutes.

The treatments consisted of four concentrations of salts of MS medium (25, 50, 75 and $100 \%)$ and three types of supplementation: coconut water $\left(100 \mathrm{~mL} \mathrm{~L}^{-1}\right)$, dwarf banana pulp (Musa spp) $\left(60 \mathrm{~g} \mathrm{~L}^{-1}\right)$ and no supplementation, resulting in a $3 \times 4$ factorial and 12 treatments. Each treatment was repeated three times for a total of 36 plots where each plot consisted of 10 flasks with one seed in each. The experimental design was completely randomized.

After inoculating the explants, the flasks were placed in a growth chamber at $25^{\circ} \mathrm{C} \pm 1{ }^{\circ} \mathrm{C}$ and with a photoperiod of 16 hours/day. Light was provided by fluorescent lamps (cool white) with a luminescent intensity of $25 \mu \mathrm{mol} \mathrm{m} \mathrm{s}^{-2}$.

The following characteristics were evaluated two months after seedling development: germination rate (successful germination was determined by the appearance of a shoot or visible and developed radicle) (GER), shoot length (SL), largest root length (RL), dry mass (DM), fresh mass (FM), stem diameter (DIA), number of leaves (NL), chlorophyll A (CA), chlorophyll B (CB), total chlorophyll (CT).

The resulting data were submitted to analysis of variance using the SISVAR (Sistema para Análise de Variância) computer program (FERREIRA, 2000). When the value of $F$ was significant, the qualitative means were compared by the Tukey test and the MS concentrations were submitted to polynomial regression at the 5\% level.

\section{RESULTS AND DISCUSSION}

None of the MS salt concentrations or supplement types had any significant effect on dry mass (DM), germination rate (GER), chlorophyll A (CA), chlorophyll B (CB) or total chlorophyll (CT). For the remaining characteristics, there were significant effects from isolated factors except fresh mass (FM) and largest root length (RL) where interaction between MS salt concentration and supplement type was significant.

The Falker index showed that average levels of A, B and total chlorophyll $(42.23,22.25$ and 64.49 respectively) did not differ among treatments. Chlorophyll content was positively correlated with plant $\mathrm{N}$ content and crop yield. This relation is mainly attributed to the fact that 50 to $70 \%$ of the total $\mathrm{N}$ in leaves is in enzymes that are associated with chloroplasts (SINGH et al, 2010; REINBOTHE et al., 2010). MS medium is rich in nitrate and ammonia ions, which helps explain why 
the Falker index did not differ among treatments regardless of MS salt concentration or supplement type. Plants that are native to the Cerrado do not typically have high nutritional demands. Consequently, higher or lower nitrogen concentrations in the crop medium probably did not influence the efficiency of nitrogen absorption and, consequently, did not lead to quantitative differences in the synthesis of this molecule by the barueiro seedlings.

Fresh mass was not strongly influenced by any of the supplements tested in this study. The only observed difference was between pure MS and MS supplemented with banana pulp at a concentration of $75 \%$ (Table 1). This demonstrates that this supplement did not increase the biomass of the seedlings at this specific concentration. Although there was significant interaction between the factors for fresh mass, regressions of the saline concentrations supplemented with coconut water and banana pulp were not significant and were therefore discarded. The regression considers the treatments without supplements. Figure 1 shows that MS concentrations above $70 \%$ are associated with lower fresh mass values for $D$. alata. The first derivative of this regression equation shows that a maximum biomass of $3,40 \mathrm{~g}$ was achieved at a $71 \%$ salt concentration. The default concentration of MS was also inadequate in the in vitro cultivation of Syngonanthus elegantulus (PÊGO et al., 2013). This occurred because this species is adapted to less fertile sandy soils and consequently requires lower levels of nutrients to develop properly. This explanation is consistent with the nutritional demands of barueiro. In addition to having the lowest increase in fresh mass, seedlings cultivated in the pure MS medium also had the lowest values for leaf number and height and showed symptoms of leaf phytoxicity. Superior development in artificial media with lower levels of nutrients may have occurred because barueiro is adapted to soils with low fertility.

Table 1. Mean fresh mass (g) of barueiro (Dipteryx alata Vog.) seedlings grown in four different concentrations of MS media, either pure or supplemented with coconut water or banana pulp. Uberlândia, MG, Brazil, 2014.

\begin{tabular}{lllll}
\hline & \multicolumn{4}{c}{ MS salt concentration (\%) } \\
\hline Treatment & $\mathbf{2 5}$ & $\mathbf{5 0}$ & $\mathbf{7 5}$ & $\mathbf{1 0 0}$ \\
\hline Pure MS & $2.87 \mathrm{~A}$ & $3.03 \mathrm{~A}$ & $3.63 \mathrm{~A}$ & $3.04 \mathrm{~A}$ \\
Coconut water & $3.01 \mathrm{~A}$ & $3.03 \mathrm{~A}$ & $3.15 \mathrm{AB}$ & $2.55 \mathrm{~A}$ \\
Banana pulp & $3.05 \mathrm{~A}$ & $2.89 \mathrm{~A}$ & $2.64 \mathrm{~B}$ & $2.97 \mathrm{~A}$ \\
\hline
\end{tabular}

$$
\mathrm{CV}=10.67 \%, \mathrm{LSD}=0.65
$$

Means followed by the same capital letter within a column do not differ by the Tukey test at $5 \%$ probability. CV: coefficient of variation. LSD: least significant difference.

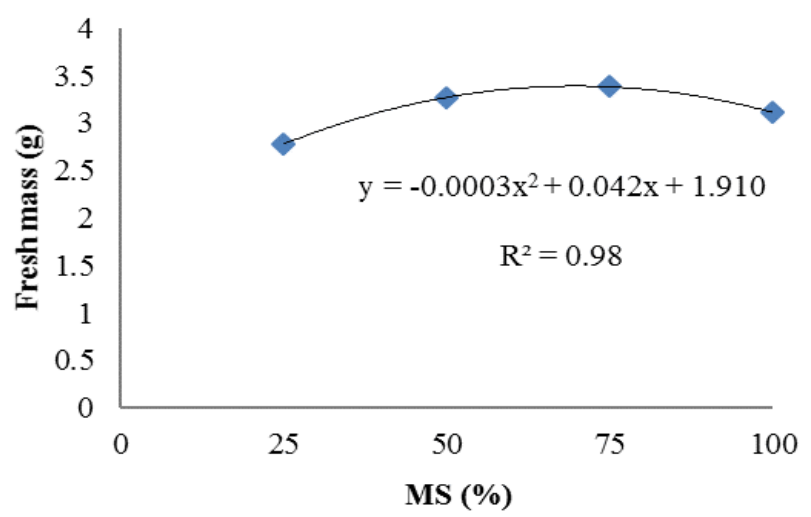

Figure 1. Fresh mass of barueiro (Dipteryx alata Vog.) seedlings grown in different concentrations of MS medium. Uberlândia, MG, Brazil, 2014. 
The banana pulp supplement was unfavorable to shoot development given that it produced results that were lower than those achieved in the treatment without supplementation (Figure 2A). This result differs from that of Pasqual et al., (2009) who worked with Cattleya loddigesii and obtained positive in vitro growth responses using this supplement. Silva et al. (2005) states that banana pulp may provide amino acids and vitamins that increase the fresh mass of orchid species. However, for barueiro, the addition of these components to the salts of the MS medium may have created a nutritional imbalance that inhibited shoot growth in a species that is native to the Cerrado and adapted to nutrient restrictions. The treatment supplemented with coconut water did not differ from the other treatments regarding shoot length. Although this liquid endosperm benefited the vegetative structure, its use does not appear to be advantageous since the seedlings were equally successful in its absence. The root quantity formed in vitro provides greater root/plant contact surface, allowing greater nutrient absorption. The vigorous root system developed by barueiro allows greater optimization of nutrients, even in media with limited nutrition.

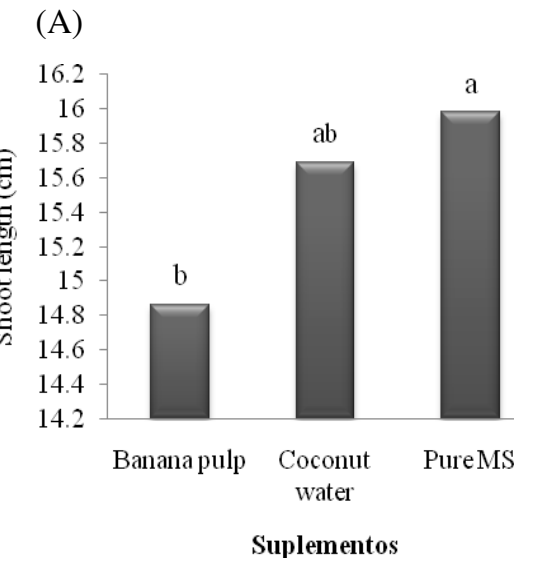

Regression analysis shows that MS salt concentrations above $25 \%$ negatively affected shoot length (Figure 2B). Similar results were also found in studies on the in vitro cultivation of genipapeiro (ALMEIDA et al., 2013), mangabeira (LÉDO et al., 2007) and vine species (DZAZIO et al., 2002), in which half-strength concentrations of MS produced the best shoot development in seedlings. However, these data contradict those obtained in a study on Stanhopea tigrina (MARTÍNEZ; GARCÍA, 2007) where the best shoot development occurred when the seedlings were cultivated in pure MS supplemented with higher concentrations of coconut water $\left(120 \mathrm{~mL} \mathrm{~L}^{-1}\right)$ and banana pulp $\left(100 \mathrm{~g} \mathrm{~L}^{-1}\right)$ than those used in the current study. Furthermore, a study on Cattleya loddigesii (PASQUAL et al., 2009) showed that $200 \mathrm{~g} \mathrm{~L}^{-1}$ of banana pulp promoted greater seedling vigor. The differences in these results may be due to the specifications of the culture medium for different species since different combinations of carbohydrates, minerals, vitamins and growth regulators stimulate (or not) the growth of organs, tissues, cells and plant development (George et al., 2008), as is clearly shown by the current study.

(B)

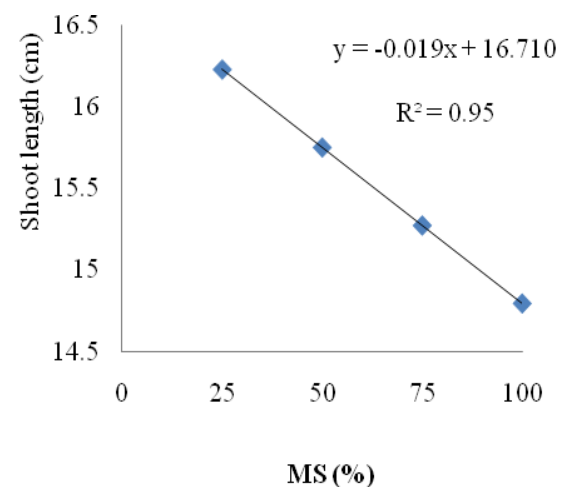

Figure 2. Shoot length of barueiro (Dipteryx alata Vog.) seedlings cultivated in pure MS medium, supplemented with banana pulp and coconut water (A) and with different MS salt concentrations (B). Uberlândia, MG, Brazil, 2014.

The pure MS medium or the same supplemented with coconut water produced the best seedling root development, and did not differ among almost all of the salt concentrations tested (Table 2). The treatments supplemented with banana pulp resulted in low levels of root growth. According to Torres and Barbosa (2001), banana pulp can promote different effects in in vitro cultivation, such as root thickening or root growth, depending on the cultivar and the amount of pulp used. However, in the current study, this supplement was not beneficial because it produced the lowest levels of root growth at the $75 \%$ concentration of MS salts (Table 2). Regression analysis showed that root growth resumed at concentrations greater than $75 \%$ of MS salts (Figure 3A). The MS medium containing significant concentrations of ammonium ions, nitrite and nitrate, which in turn exert great importance in controlling the $\mathrm{pH}$ of the culture medium, acting as buffering agent and favor the absorption of other ions present in the medium (NAGAO et al., 1994). In this context, in concentrations above $75 \% \mathrm{MS}$ salts, the buffer effect was noted, which may be favored by higher adsorption seedling nutrients 
banana pulp, resulting in restoration of root growth. The process of root growth was impaired linear with MS concentration, whether pure or supplemented with coconut water (Figures $3 \mathrm{~B}$ and $3 \mathrm{C}$ ), suggesting that barueiro roots develop better in cultivation media with lower concentrations of salt as would be expected given the low nutritional requirements of this native plant. Evidently, different culture media can produce diverse effects in different species. Some species require more complex culture media (JU SU; SCHNITZER; FARIA, 2012) while other require more diluted compositions.

Table 2. Mean length of the largest root $(\mathrm{cm})$ of barueiro (Dipteryx alata Vog.) seedlings grown in four concentrations of pure MS or supplemented with coconut water or banana pulp. Uberlândia, MG, Brazil, 2014.

\begin{tabular}{llllc}
\hline & \multicolumn{4}{l}{ MS salt concentration (\%) } \\
\hline Treatment & $\mathbf{2 5}$ & $\mathbf{5 0}$ & $\mathbf{7 5}$ & $\mathbf{1 0 0}$ \\
\hline Pure MS & $28.96 \mathrm{AB}$ & $29.52 \mathrm{~A}$ & $28.00 \mathrm{~A}$ & $23.04 \mathrm{~A}$ \\
Coconut water & $35.15 \mathrm{~A}$ & $28.15 \mathrm{~A}$ & $19.67 \mathrm{~B}$ & $18.81 \mathrm{~A}$ \\
Banana pulp & & & $12.72 \mathrm{C}$ & $19.98 \mathrm{~A}$ \\
\hline
\end{tabular}

$$
\mathrm{CV}=13.09 \%, \mathrm{LSD}=6.40
$$

Means followed by the same capital letter within a column do not differ by the Tukey test at $5 \%$ probability. CV: coefficient of variation. LSD: least significant difference.
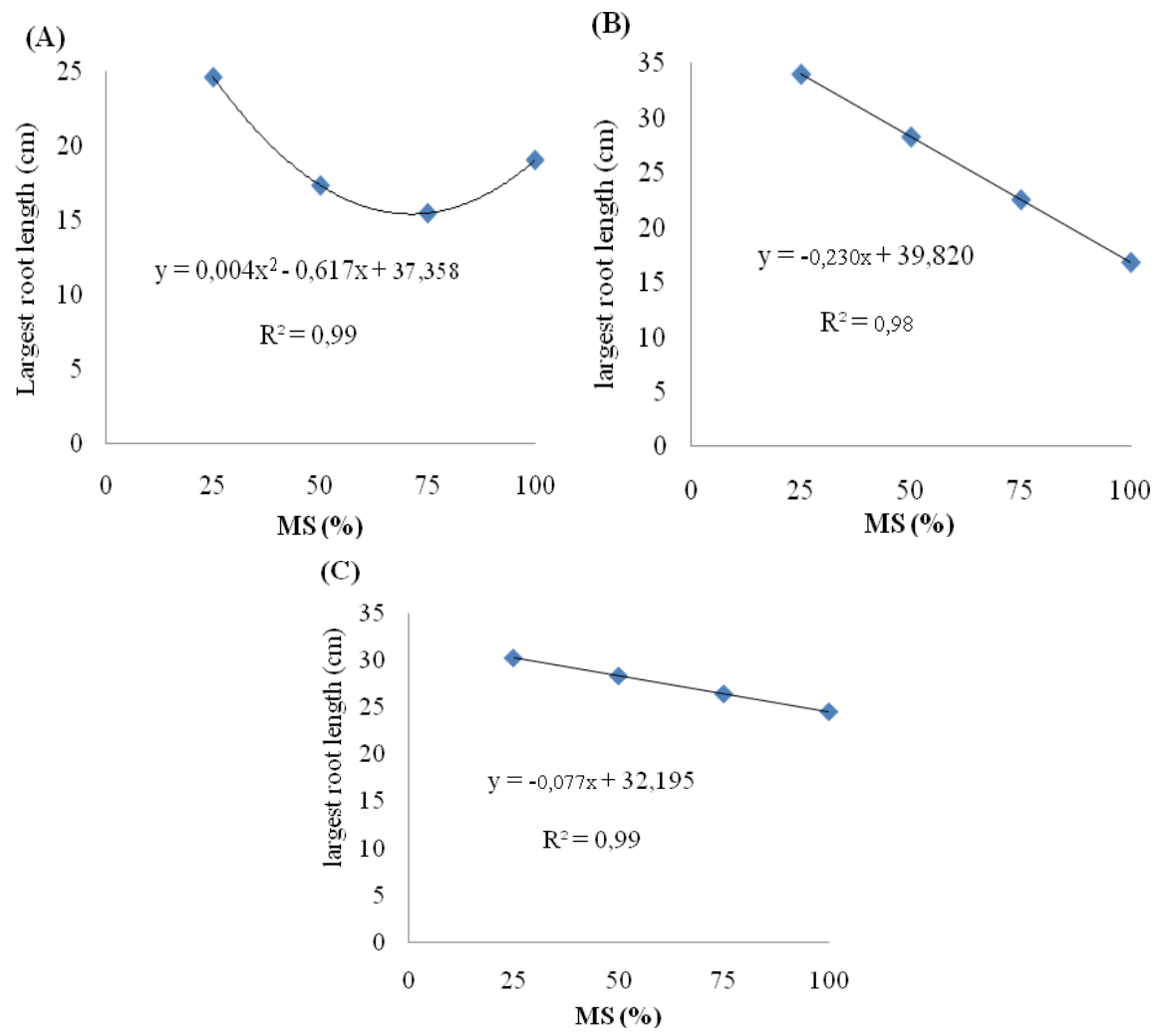

Figure 3. Length of the largest root $(\mathrm{cm})$ of barueiro (Dipteryx alata Vog.) seedlings grown in the MS medium supplemented with (A) banana pulp, (B) coconut water and (C) without supplement. Uberlândia, MG, Brazil 2014. 
Similar to many species of the Cerrado, barueiro seedlings require lower levels of nutrients during development. This was evidenced in the current study by the reduced development of roots and stems when the seedlings were grown in the pure MS medium. These results agree with those obtained by Soares et al. (2011) where an original MS medium was unfavorable in the development of seedlings of another native fruit tree of the Cerrado, Acrocomia aculeata. Malavolta (2006) explains that any nutrient in excess causes nutritional imbalances that inhibit seedling development, as observed in the present study.

Based on the diameter of the seedlings, neither of the supplements (coconut water and banana pulp) proved to be advantageous because neither differed from the pure MS medium. The number of leaves on seedlings grown in pure MS surpassed that of the seedlings grown with the banana pulp supplement (Table 3). A study on Jatropha curcas (NUNES et al., 2008) showed that coconut water supplementation up to $250 \mathrm{~mL} \mathrm{~L}^{-1}$ had a strongly positive, linear effect on leaf production. Banana pulp, on the other hand, does not seem to supply the nutritional resources needed to induce greater leaf numbers. Leaf numbers of Dendrobium nobile (SOARES et al., 2011) for example, did not differ between treatments with a banana pulp additive and those using only unmodified MS, whereas an additive of coconut water $\left(200 \mathrm{~mL} \mathrm{~L}^{-1}\right)$ resulted in young plants with larger diameter pseudobulbs.

Table 3. Mean diameter ( $\mathrm{mm}$ ) and leaf number of barueiro (Dipteryx alata Vog.) seedlings grown in pure MS medium, with coconut water and with banana pulp. Uberlândia, MG, Brazil, 2014.

\begin{tabular}{lll}
\hline Treatment & Diameter $(\mathbf{m m})$ & Number of leaves \\
\hline Pure MS & $4.28 \mathrm{AB}$ & $27.36 \mathrm{~A}$ \\
Coconut water & $3.97 \mathrm{~B}$ & $23.86 \mathrm{AB}$ \\
Banana pulp & $4.41 \mathrm{~A}$ & $20.52 \mathrm{~B}$ \\
& & \\
\hline CV & $8.37 \%$ & $14.84 \%$ \\
LSD & 0.36 & 3.62
\end{tabular}

Means followed by the same capital letter within a column do not differ by the Tukey test at $5 \%$ probability. CV: coefficient of variation. LSD: least significant difference.

According to Pedroso de Moraes et al., (2009), fruit pulp and liquid endosperm serve as complements to culture media, especially regarding potassium and phosphate salts and phytohormones. However, whether this additional nutrient load is viable or not, is dependent on the plant species in question. Unlike several herbaceous and some woody species, the natural additives used in the present study did not produce any advantages for barueiro compared to the basic MS medium.

The best results in the present study were obtained by reducing the concentration of MS salts. This same strategy has been adopted in other in vitro studies aimed at the economic and physiological advantages of the seedlings. Similarly, a study by Teixeira (2001) showed that reducing the original macronutrient concentration of the MS medium by $50 \%$ increased the establishment and proliferation efficiency of the shoots of peach palm explants. This same reduction in MS concentration also produced better results for the in vitro establishment of Aniba canelilla. According to the authors of this study, the reduction in salts, vitamins and other components of the culture medium reduced costs and allowed better control over the release of antioxidant compounds (RAMOS et al., 2013). This in turn is an important factor when working with woody plants and one of the obstacles to the conservation and multiplication of these species.

\section{CONCLUSIONS}

Coconut water and banana pulp supplements provided no advantage for the in vitro development of barueiro seedlings, whereas the pure MS medium best met the initial requirements of this species.

A $25 \%$ concentration of MS salts was the best option for the in vitro establishment of Dipteyx alata. 


\section{ACKNOWLEDGEMENTS}

This study was made possible by financial support from CNPq and FAPEMIG.

RESUMO: O barueiro (Dipteryx alata Vog.) é uma fruteira nativa do bioma Cerrado e possui várias aplicabilidades, desde alimentares até medicinais. No entanto ainda não é uma espécie domesticada e encontra-se sob risco projetado de extinção. A cultura de tecidos vegetais constitui uma importante ferramenta para a conservação de germoplasma, além de proporcionar a rápida propagação de mudas de qualidade em larga escala. Porém, esta técnica não vem sendo utilizada em barueiro, podendo ser aplicada de forma valiosa contribuindo para seu processo de domesticação. Objetivou-se neste trabalho avaliar concentrações de sais do meio MS (25, 50, 75 e 100\%) suplementados com água de coco $\left(100 \mathrm{~mL} \mathrm{~L}^{-1}\right)$, polpa de banana nanica $\left(60 \mathrm{~g} \mathrm{~L}^{-1}\right)$ ou ausência de suplemento no estabelecimento in vitro de sementes de barueiro (Dipteryx alata Vog). O delineamento experimental utilizado foi o inteiramente casualizado (DIC) em esquema fatorial $3 \times 4$ (três meios de cultivo e quatro doses de sais MS) com três repetições. Foram avaliadas as características: taxa de germinação, comprimento da parte aérea e da maior raiz, diâmetro do caule, número de folhas, teores de clorofila A, B e total, massa fresca e massa seca das plântulas. A água de coco e a polpa de banana como suplementos não forneceram vantagens no desenvolvimento in vitro de plântulas de barueiro e a concentração plena dos sais MS não forneceram vantagens ao desenvolvimento inicial das plântulas. Portanto, o meio MS puro a uma concentração de $25 \%$ dos sais MS é a formulação que melhor se aplica para o estabelecimento in vitro de Dipteyx alata.

PALAVRAS-CHAVE: Suplementos naturais. Meio de cultura. Fruteira do Cerrado. Baru.

\section{REFERENCES}

ALMEIDA, C. S.; LÉDO, A. S.; ARAÚJO, A. G.; SILVA, A. V.; SILVA JÚNIOR, J. S.; SANTOS, J. E.; RIBEIRO, M. M. J.; VILANOVA NETA, J. L. Efeito do meio de cultura na germinação in vitro do jenipapeiro. Scientia Plena, Aracaju, v. 9, n. 10, p. 1-6, 2013.

ARAUJO, A. G.; PASQUAL, M.; SILVA, A. B.; VILLA, F.; ROCHA, H. S.; COSTA, F. C. Propagação in vitro de plântulas de orquídea em diferentes meios de cultura e concentrações de citocinina. Plant Cell Culture and Micropropagation, Lavras, v. 2, n. 2, p. 68-73, 2006 a.

ARAUJO A. G; PASQUAL, M.; VILLA, F.; COSTA F. C. Água de coco e polpa de banana no cultivo in vitro de plântulas de orquídea. Revista Ceres, Viçosa, v. 53, n. 310, p. 608-613. 2006 b.

CALDAS, L. S.; HARIDASAN, P.; FERREIRA, M. E. Meios nutritivos. In: TORRES, A. C.; CALDAS, L. S.; BUSO, J. A. (eds). Cultura de tecidos e transformação genética de plantas. Brasília: EMBRAPA/ CNPH. 1998. p. 87-132.

CAMPOS, D. M. Reprodução por sementes em laboratório caseiro. 1. Rio de Janeiro: Expressão e Cultura, 100 p. 2010.

DZAZIO, P. M.; BIASI, L. A.; ZANETTE, F. Micropropagação do porta-enxerto de videira '420-A'. Revista Brasileira de Fruticultura, Jaboticabal, v. 24, n. 3, p. 759-764, 2002.

FERREIRA, D. F. Sistema de análise de variância. Versão 4.0Lavras: UFLA, 2000. (Software estatístico)

FERREIRA, R. A.; BOTELHO, S. A.; DAVIDE, A. C.; MALAVASI, M. M. Caracterização morfológica de fruto, semente, plântula e muda de Dipteryx alata Vogel - baru (Leguminosae Papilionoideae). Cerne, Lavras, v.4, n.1, p. $73-87,1998$.

GEORGE, E. F.; HALL, M. A.; DEKLERK, G. J. Plant propagation by tissue culture. Dordrecht: The Background, 2008. 501p. 
GRATTAPAGLIA, D.; MACHADO, M. A. Micropropagação. In: TORRES, A. C.; CALDAS, L. S.; BUSO, J. A. (Eds.). Cultura de tecidos e transformação genética de plantas. Brasília, DF: Embrapa-SPI/EmbrapaCNPH, 1998. p. 183-260.

JUNQUEIRA, N. T. V., JUNQUEIRA, K. P., PREREIRA, A. V., PEREIRA, E. B. C., BRAGA, M. F., CONCEIÇÃO, L. D. H. C. S., FALEIRO, F. G. Fruteiras Nativas do Cerrado: o extrativismo e a busca da domesticação. XXII Congresso Brasileiro de Fruticultura. Bento Gonçalves, 2012.

JU SU, M.; SCHNITZER, J. A.; FARIA, R. T. Polpa de banana e fertilizantes comerciais no cultivo in vitro de orquídea. Científica, v.40, n.1, p.28-34, 2012.

LÉDO, A. S.; SECA, G. S. V.; BARBOZA, S. B. S. C.; SILVA JÚNIOR, J. B. Crescimento inicial de mangabeira (Hancornia speciosa) em diferentes meios de germinação in vitro. Ciência e Agrotecnologia, Lavras, v. 5, n. 4, p. 989-993, 2007.

MALAVOLTA, E. Manual de nutrição mineral de plantas. Piracicaba: POTAFOS, 2006. 638p.

MARTINELLI, G.; MORAES, M. A. Livro vermelho da flora do Brasil. Rio de Janeiro: Andrea Jakobsson: Instituto de Pesquisas Jardim Botânico do Rio de Janeiro, 2013. 1100 p.

MARTÍNEZ, D. M.; GARCÍA, R. A. M. Efecto de los compuestos orgánicos en la propagación in vitro de Stanhopea tigrina bateman (Orchidaceae). Foresta Veracruzana, Xalapa, v. 9, n. 2, p. 27-32, 2007.

MURASHIGE, T., SKOOG, F. Manipulation of organ initiation in plant tissue cultures. Bot. Bull. Academia Sinica, Shanghai, v. 18, p.1-24, 1977.

NAGAO, E. O.; PASQUAL, M.; RAMOS, J. D. Efeitos da sacarose e do nitrogênio inorgânico sobre a multiplicação "in vitro" de brotações de porta-enxerto de citros. Bragantia, Campinas, v. 53, n. 1, p. 25-31, 1994. http://dx.doi.org/10.1590/S0006-87051994000100003

NOGUEIRA, R. C.; PAIVA, R.; CASTRO, A. H.; VIEIRA, C. V.; ABBADE, L. C.; ALVARENGA, A. A. Germinação in vitro de Murici-Pequeno (Byrsonima intermedia A. Juss.). Ciência e Agrotecnologia, Lavras, v. 28, n. 5, p. 1053-1059, 2004.

NUNES, C. F.; PASQUAL, M.; SANTOS, D. N.; CUSTÓDIO, T. N.; ARAÚJO, A. G. Diferentes suplementos no cultivo in vitro de embriões de pinhão-manso. Pesquisa Agropecuária Brasileira, Brasília, v. 43, n. 1, p. 914, 2008. http://dx.doi.org/10.1590/S0100-204X2008000100002

PASQUAL, M.; FIGUEIREDO, M. A.; REZENDE, J. C.; ARAÚJO, A. G.; SANTOS, F. C.; FERREIRA, E. A.; JUNQUEIRA, K. P. Fontes de nitrogênio, polpa de banana e ágar no desenvolvimento in vitro de plântulas de orquídea. Horticultura brasileira, Brasília, v. 27, n. 2, p. 211-216, 2009.

PEDROSO DE MORAES, C.; DIOGO, J. A.; PEDRO, N. P.; CANABRAVA, R. I.; MARTINI, G. A.; MARTELINE, M. A. Desenvolvimento in vitro de Cattleya loddigesii Lindley (Orchidaceae) utilizando fertilizantes comerciais. Revista Brasileira de Biociências, Porto Alegre, v.7, n.1, p.67-69, 2009.

PÊGO, R. G.; PAIVA, P. D. O.; PAIVA, R. Micropropation of Syngonanthus elegantulus. Ciência e Agrotecnologia, Lavras, v. 37, n. 1, p. 32-39, 2013.

PINHEIRO, C. S. R.; MEDEIROS, D. N.; MACÊDO, C. E. C.; ALLOUFA, M. A. I. Germinação in vitro de mangabeira (Hancornia speciosa Gomez) em diferentes meios de cultura. Revista Brasileira de

Fruticultura. Jaboticabal, v.23, n. 2, p. 413-416, 2001. 
RAMOS, S. L. F.; LOPES, M. T. G.; SAMPAIO, P. T. B.; CHAGAS, E. A.; PASQUAL, M.; SILVA, P. P. Tipo de explante e diferentes concentrações de sais em meio de cultura MS no estabelecimento in vitro de Aniba canelilla. Revista Ciências Agrárias. Recife, v. 56, n. 4, p. 376-379, 2013.

REINBOTHE, C.; BAKKOURI, M.; BUHR, F.; MURAKI, N.; NOMATA, J.; KURISU, G.; FUJTAA, Y. E REINBOTHE, S. Chlorophyll biosynthesis: spotlight on protochlorophyllide reduction. Trends in Plant

Science, Oxford, v.15, n.11, p. 614-624, 2010. http://dx.doi.org/10.1016/j.tplants.2010.07.002

SANO, S. M.; RIBEIRO, J. F.; BRITO, M. A. de. Baru: biologia e uso. Documentos, 116. Planaltina, DF: Embrapa Cerrados, 2004. 52 p.

SILVA, D. B.; SILVA, J. A.; JUNQUEIRA, N. T. V.; ANDRADE, L. R. M. Frutas do Cerrado. Brasília: Embrapa Informações Tecnológica, 2001. 179 p.

SILVA, E. F.; PASQUAL, M.; PAIVA, P. D. O.; SILVA, A. B.; NOGUEIRA, D. A. Polpa de banana e vitaminas do meio MS no cultivo in vitro de orquídea. Plant Cell Culture e Micropropagation, v. 1, n. 1, p. 8-12, 2005.

SINGH, V.; SINGH, B.; SINGH, Y.; THIND, H. S. E GUPTA, R. K. Need based nitrogen management using the chlorophyll meter and leaf colour chart in rice and wheat in South Asia: a review. Nutrient Cycling Agroecosyst, Dordrecht, v.88, v. 3, p. 361-380, 2010.

SOARES, J. D. R.; RODRIGUES, F. A.; PASQUAL, M.; NUNES, C. F.; ARAÚJO, A. G. Germinação de embriões e crescimento inicial in vitro de macaúba. Ciência Rural, Santa Maria, v.41, n.5, p.773-778, 2011. http://dx.doi.org/10.1590/S0103-84782011005000040

SU, M. J.; SCHNITZER, J. A.; FARIA, R. T. Polpa de banana e fertilizantes no cultivo in vitro de orquídea. Científica, Jaboticabal, v.40, n.1, p. 28-34, 2012.

TEIXEIRA, J. B. Limitações ao processo de cultivo in vitro de espécies lenhosas. Brasília: Embrapa Recursos Genéticos e Biotecnologia, 2001.

TORRES, A. C.; BARBOSA, N. V, WILLADINO, L.; GUERRA, M. P.; FERREIRA, C. F.; PAIVA, S. A. V. Meio e condições de incubação para cultura de tecidos de plantas. Brasília, DF: Embrapa Hortaliças (Circular Técnica). 20p. 2001.

TORRES, A. C.; BARBOSA, N. V. R. Condições de incubação para cultura in vitro. ABCTP Notícias, Lavras, p.1-7, 2001.

VIEIRA, J. G. Z.; UNEMOTO, L. K.; YAMAKAMI, J. K.; NAGASHIMA, G. T.; FARIA, R. T.; AGUIAR, R. S. Propagação in vitro e aclimatização de um híbrido de Cattleya Lindl. (Orchidaceae) utilizando polpa de banana e água de coco. Científica, Jaboticabal, v. 37, n. 1, p. 48-52, 2009. 